\title{
NESTING ASSOCIATIONS OF WASPS AND ANTS ON LOWLAND PERUVIAN ANT-PLANTS
}

\author{
By Edward Allen Herre, ${ }^{1,2}$ Donald M. Windsor, ${ }^{1}$ \\ and Robin B. Foster ${ }^{1}$
}

\section{INTRODUCTION}

Neotropical vespid wasps are known to form nesting associations with other species of wasps and ants. For instance, Mischocyttarus immarginatus nests primarily in association with the larger and more aggressive colonies of certain polybiine wasps in the savannas of northwestern Costa Rica (Windsor 1972, 1973). Examples of wasp species which form interspecific nesting associations with ants include Polybia rejecta and Synoeca chalybea, whose nests are usually associated with carton building Azteca spp. ant colonies throughout the neotropics (Vesey-Fitzgerald 1938, Richards 1945, DMW, RBF, EAH personal observations).

Often the ants with which wasps nest are involved in more or less specific associations with host ant-plants. In addition to Azteca spp., Polybia rejecta nests can be found in ant acacias which support healthy colonies of Pseudomyrmex ferruginea (DMW, RBF personal observations). Zikan (1949) has reported that several Mischocyttarus species nest on the ant plant Cordia nodosa (Boraginaceae) inhabited by Azteca spp. and an unidentified species of myrmecaceous Melastomataceae. Richards (1945) reported collecting at least one nest of $M$. metoecus and $M$. decimus from $C$. nodosa in Guyana.

Why do these nesting associations exist? Windsor (1972, 1973) demonstrated that Mischocyttarus immarginatus nests associated with nests of other, more aggressive wasps species survive longer and produce more brood. It appears that such nests suffer less damage from birds which destroy nests and rob brood. Richards (1951) suggested that nesting with ants such as Azteca may be one of relatively few possible defenses available to tropical wasps against

\footnotetext{
'Smithsonian Tropical Research Institute, Box 2072, Balboa, Republic of Panama 2Department of Biology, University of Iowa, Iowa City, Iowa 52242, U.S.A. Manuscript received by the editor March 20, 1986
} 
the organized raids of army ants (Ecitonini). Below we describe numerous species of vespid wasps which form nesting associations with Allomerus octoarticulatus ants inhabiting the plant Tococa guianensis Aublet (Melastomataceae) and with Pheidole spp. ants inhabiting Maieta poeppigii Mart. ex Triana (Melastomataceae) and show that by nesting on these plants the wasps escape army ant raids.

\section{Study Area}

The study site is in Loreto, Peru, at Estacion Biologica Callicebus which is located 3-5 km. south of the village of Mishana on the Rio Nanay in Loreto, Peru. The village is approximately $30 \mathrm{~km}$. east of the confluence of the Nanay with the Amazon River near Iquitos. The Estacion consists of a forest camp and an extensive trail network through the apparently uncut and non-indundated forest. The forest grows on low hills composed of a mosaic of white sand and dark brown sand and is drained by tea-colored streams. These sediments are derived from the ancient Guiana and Brazilian Shields and have been eroded and redeposited following the Andean uplift. White sand areas, though common in the Rio Negro drainage, are infrequent in the Western Amazon (see Kinsey \& Gentry, 1979). The brown sand soils support a flora typical of much of the nonindundated Peruvian Amazon. The white sand soils have a distinctive flora which shows strong affinities to the flora of the Guiana Highlands. The latter areas also have a shorter forest canopy $(20 \mathrm{~m}$. vs. 30-35 m.); fewer lianas, straighter, thinner, and less-branched understory trees and shrubs; and a thick mat of roots over the white sand. The observations presented below were collected during 8 short visits (4 by EAH in August 1978, October 1978, in December 1979, and in June 1983; 1 by DMW in November 1978; and 3 by RBF in August 1974, 1978, and 1980).

\section{OBSERVATIONS AND RESULTS}

Understory ant-plants are common at Mishana, especially on the brown sand soils, and are represented by a diversity of families: (Melastomataceae) Tococa (3 spp.), Maieta (2 spp.); (Chrysobalanaceae) Hirtella (2 spp.); (Boraginaceae) Cordia nodosa; (Rubiaceae) Duroia hirsuta. Of these, only Tococa guianensis is abundant on the white sand areas. This $2-4 \mathrm{~m}$. treelet is most common on 
upper slopes and hilltops, primarily in gaps formed by treefalls. The population is polymorphic for a bright red-purple color on the undersides of the leaves. The petioles have a large, bilobed, hollow expansion (formicarium) with a pair of openings onto the undersides of the leaf blade (see figure 1). Maieta poeppigii, in contrast, is an arching shrub less than $1 \mathrm{~m}$. tall most common on brown sand soils, primarily on lower slopes and streambanks. The formicarium of Maieta consists of a pair of raised, hollow chambers on either side of the midrib at the base of the leafblade.

Although we found colonies of at least eight different species of ants inhabiting different Tococa guianensis individuals (eg. Azteca spp., Dolichoderus spp., Pseudomyrmex spp., Crematogaster spp., and Gnamtogenys spp.), the majority of the plants we encountered were occupied by colonies of the ant Allomerus octoarticulatus (Allomerus) (18 of 34 plants in one census). Allomerus builds a characteristic carton tunnel of cemented debris with small holes regularly spaced over the surface (see figure 1). These structures envelope most of the stems, connect the formicaria, and extend down the main stem to within $20 \mathrm{~cm}$. of the ground. Most ant activity is confined to the formicaria and these tunnels. Unlike other species of ants which we observed on these plants, we did not observe Allomerus foraging off the host plant either on any casually observed plants or on focal plants watched at hourly intervals between $5 \mathrm{am}$. and $1 \mathrm{am}$. In addition, the presence of coccids and structures which may have been food bodies or feeding glands for the ants (see Roth, 1970) led us to believe that Allomerus derives all its nutrition either directly or indirectly from the host $T$. guianensis, much as Pseudomyrmex satanica is supported by farming coccids within the hollow outer twigs of Triplaris cumminghami (DMW, personal observation in Costa Rica). Allomerus aggressively recruits onto leaf surfaces when a plant is disturbed. However, the ants do not harm wasp broods although they will swarm all over the wasp nest.

Maieta poeppigii plants were overwhelmingly occupied by Pheidole spp. ants (94 of 101 plants). Unlike Allomerus, the Pheidole $s p p$. do not build tunnels, although they do characteristically store debris in one of the two paired chambers at the base of each leaf. The Pheidole spp. ants are not particularly aggressive. Occasional minor workers can be found outside the formicaria. Major workers and minor workers emerge from the formicaria in large numbers 


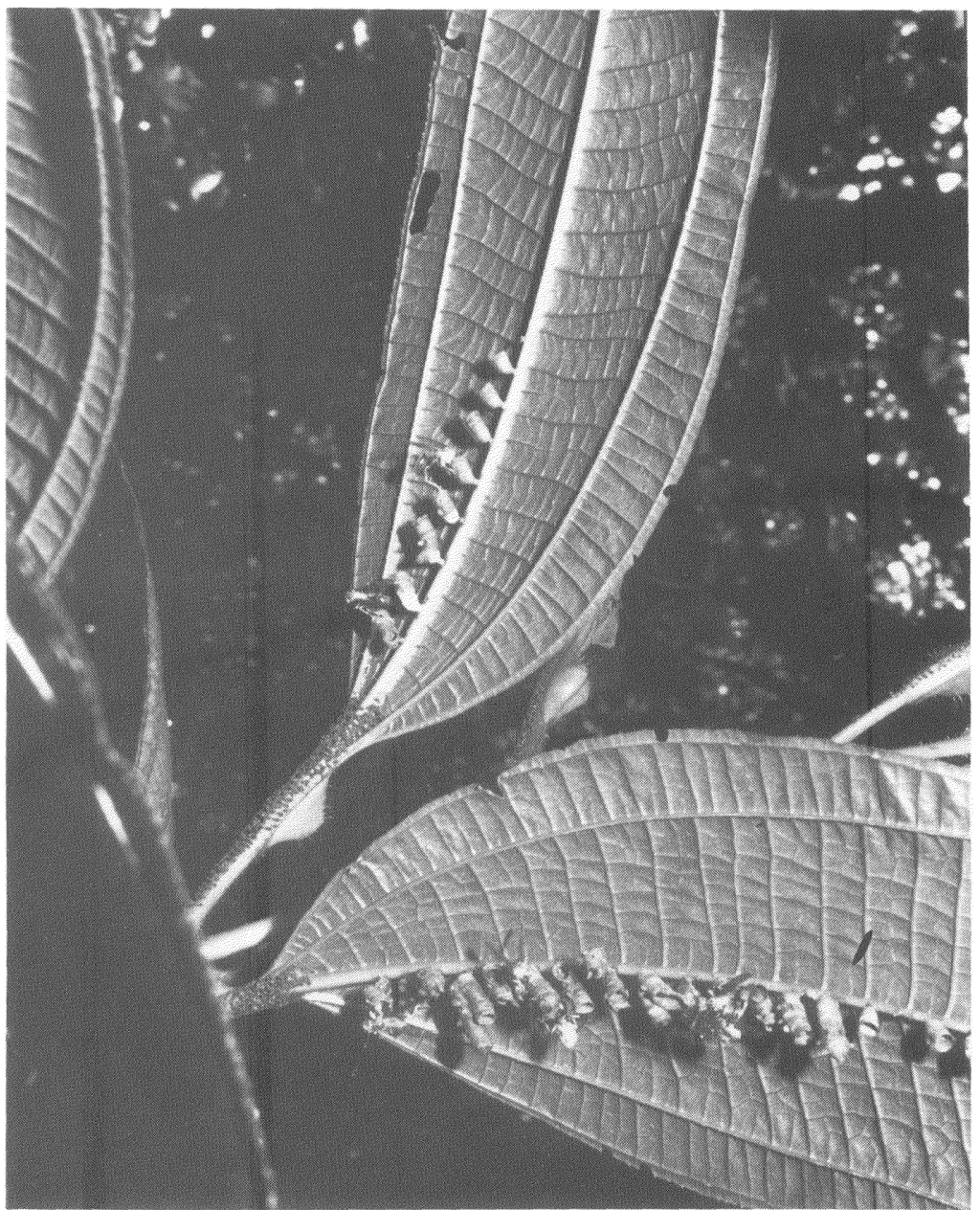

Figure 1. Nests and adults of the wasp Mischocyttarus insolitis shown beneath the leaves of Tococa guianensis plants inhabited by Allomerus octoarticulatus ants. Notice the separation of the cells on the multiple pedicels. Also notice the characteristic carton tunneling and formicaria used by the Allomerus ants 
only if the leaves are violently shaken or if the formicaria are directly disturbed. The Pheidole ants were not observed on the wasp nests.

Of those wasps which construct small open nests, we found ten Mischocyttarus species and one Polistes species in the forest understory. All but two of thirty-one active colonies encountered occurred on the undersides of Tococa guianensis or Maieta poeppigii leaves and only when the plants were occupied by Allomerus and Pheidole ants, respectively (see table 1). Two of the Mischocyttarus wasp species, $M$. latissimus and $M$. insolitis, build multi-pediceled nests arranged in rows along the midrib of the leaf. The cells are fused in the nests of $M$. latissimus while the nests of $M$. insolitus consist of separate clusters of one to four brood cells with each cluster supported by its own pedicle (see photograph 1). The net result is the subdivision and separation of the broodcells which comprise the nests of $M$. insolitus. The other species of Mischocyttarus build nests more typical of the genus; a cluster containing all cells supported by a single pedicel. All of the Mischocyttarus. species are extremely timid, flying away from their nests at the slightest disturbance and making no attempt at brood defense. In addition, two colonies (one each of Polybia signata and Polybia spp.) out of six total colonies of socially complex, aggressively swarming Polybiinae wasps were found attached to limbs of $T$. guianensis.

A small number of Tococa plants supported a disproportionate number of wasp colonies and this was most obvious with the nests of Mischocyttarus insolitis. In a census of $43 \mathrm{~T}$. guianensis plants with Allomerus ants, five plants were the host for single Mischocyttarus nests while seven plants had two or more colonies. In a survey of 116 Maieta poeppigii plants with Pheidole spp. ants, one plant had three nests and two plans each had one.

Several observations and manipulations we performed indicate that by nesting on these myrmecacious melastomes the wasps avoid nest plundering by army ants. While following the raiding swarms of Eciton burchelli and Eciton rapax we noticed that these ants never ran on to either Tococa guianensis or Maieta poeppigii plants. The avoidance of these two plants contrasted sharply with the army ants' rapid climbing and investigating most other plants in their path. 
Table 1. A list of wasp species collected at Mishana, 1-5 November 1978. The number of nests found on each type of host plant (Maieta, Tococa, or other) is indicated. Brachygastra melania was previously only known from Bolivia.

\begin{tabular}{|c|c|c|c|c|}
\hline Species with open nests: & $\begin{array}{l}\text { Nest } \\
\text { Found }\end{array}$ & Maieta & Tococa & other \\
\hline Mischocyttarus synoecus Rich. & Yes & 1 & & \\
\hline M. lecointei Ducke & Y & 4 & 2 & 1 \\
\hline M. pallidus Zikan & Y & 2 & & \\
\hline M. insolitus Zikan & $\mathrm{Y}$ & & 21 & \\
\hline M. latissimus Rich. & $\mathrm{Y}$ & & 2 & \\
\hline M. decimus Rich. & $\mathrm{Y}$ & & 1 & \\
\hline M. sp. near mirificus Zikan & $\mathrm{Y}$ & & & 1 \\
\hline M. carbonarius Sauss. & $\mathrm{Y}$ & & 1 & \\
\hline M. silvicola Zikan & $\mathrm{Y}$ & & 1 & \\
\hline M. sp. near interruptus Rich. & $\mathrm{Y}$ & & 1 & \\
\hline $\begin{array}{l}\text { Polistes rufiventris Ducke } \\
\text { P. pacificus }\end{array}$ & $\begin{array}{l}\mathrm{Y} \\
\mathrm{Y}\end{array}$ & (found in & $\stackrel{1}{\text { learing ne }}$ & river) \\
\hline \multicolumn{5}{|l|}{ Species with closed nests: } \\
\hline $\begin{array}{l}\text { Angiopolybia pallens Lep. } \\
\text { A. paraensis Spirola } \\
\text { morph ruficornis Ducke }\end{array}$ & $\begin{array}{l}\mathrm{Y} \\
\text { No }\end{array}$ & & & 1 \\
\hline Apoica thoracica R. du Buyss. & $\mathrm{N}$ & & & \\
\hline $\begin{array}{l}\text { Brachygastra bilineolata } \text { Spinola } \\
\text { B. buyssoni } \text { Ducke } \\
\text { B. melania } \text { Richards } \\
\text { B. moebiana } \text { Sauss. } \\
\text { B. myersi } \text { Bequaert }\end{array}$ & $\begin{array}{l}\mathrm{N} \\
\mathrm{N} \\
\mathrm{N} \\
\mathrm{N} \\
\mathrm{N}\end{array}$ & & & \\
\hline Polybia signata Ducke & $\mathbf{Y}$ & & 1 & \\
\hline P. sp. near fastidiosuscula Sauss & $\mathbf{Y}$ & & & 1 \\
\hline P. sp. & Y & & 1 & 1 \\
\hline P. rejecta $\mathrm{F}$. & $\mathbf{N}$ & & & \\
\hline P. liliaceae $\mathrm{F}$. & $\mathbf{N}$ & & & \\
\hline Protopolybia acutiscutis Cameron & $\mathbf{N}$ & & & \\
\hline Pseudopolybia vespiceps Sauss. & $\mathrm{Y}$ & & & 1 \\
\hline Stelopolybia angulicollis Spinola & $\mathbf{N}$ & & & \\
\hline Synoeca surinama Lep. & $\mathbf{N}$ & & & \\
\hline S. virginea $\mathrm{F}$. & $\mathbf{N}$ & & & \\
\hline
\end{tabular}


The perceived avoidance was substantiated when we moved a twig that the Eciton ants were using as a bridge against a stem of $M$. poeppigii. The army ants stopped when they came in contact with the stem and although ants from the rear continued moving forward until there was a great tangled mass of ants at the front, no ants crawled onto the stem. Next, we placed stems of Tococa guianensis and Maieta poeppigii with intact leaves and formicaria across active Eciton trails and found that the trails were quickly rerouted around the plants. Similar responses were not obtained when we placed other plant species or Tococa guianensis without Allomerus inhabitants across the path of the army ants. Further, in three instances, we observed army ants passing by $T$. guianensis plants with Allomerus ants and active wasps nests. We removed two $T$. guianensis leaves minus formicaria with attached wasp nests, placed them on twigs at the same height off the ground as they had been on the plants, and put the twigs in front of the Eciton raiding swarms. In both instances the army ants swiftly scaled the twigs and seized the wasp brood.

\section{Discussion}

Predatory ants pose a particularly important threat to the nests and broods of tropical wasps (Jeanne 1972, Litte 1977). In discussing this problem in his revision of the genus Mischocyttarus, Richards (1945) states, "A number of species have entered into some sort of association with ants and have thereby found safety by firmly grasping the nettle.". Clearly the wasps nesting on these plants benefit by having a neutral border maintained for them. With access to the sole connection to the terrestrial world guarded by Allomerus or Pheidole ants, there is little or no risk that hostile army ant species will come plundering down the pedicel. In this light the unusual (for Mischocyttarus wasps) nest architecture of $M$. insolitis becomes more comprehensible.

As Jeanne (1979) demonstrated, building a highly subdivided nest composed of multiple combs uses materials for nest construction very inefficiently and requires a much higher expenditure of time and energy per cell than does the nest architecture more characteristic of polistine wasps. However, a highly subdivided nest no longer provides as concentrated a target for a bird which plunders by knocking down whole nests and then leisurely eating the brood (eg. 
Windsor 1972). More passes are needed and the return in food per time and effort is less. Further, a subdivided nest is less vulnerable to being entirely wiped out by nest parasites which can move from cell to cell (eg. tineid moth larvae described by Jeanne 1979).

There appears to be no obvious benefit that the ants derive from the presence of the timid Mischocyttarus wasps. Why do the ants tolerate the presence of these wasps? A review of the ant species with which various vespid wasps are reported to form nesting associations shows that with the exception of some Azteca species, the ants all appear to be nutritionally supported by their host plants. Apparently the ants either cannot eat the wasp brood or do not recognize the wasp brood as a potential meal. Further, in the case of some ant-wasp associations such as that between Azteca spp. and Polybia rejecta, the wasps have been reported to benefit the associated ant colony by discouraging anteaters (R. Silberglied, personal communication). The Tococa guianensis plants on which the aggressive Polybia and Polistes wasps nested were difficult to approach without being stung. It is likely that the presence of these wasps reduces damage to the host plant and, consequently, the ant colony caused by mammals. Therefore, the Mischocyttarus wasps, while not being a detriment to the ants, may simply be taking good advantage of a tolerance that the ants have developed to more beneficial species of symbiotic wasps.

\section{ACKNOWLEDGMENTS}

We wish to thank Don Francisco Pizarro for generous hospitality and essential logistic help during our various visits to Casaria Mishana, Dr. William Brown for kindly indentifying all ant species mentioned, Dr. J. J. Wurdack for identifying the Tococa and Maieta species, and, especially, the late O. W. Richards for identifying the wasp species and encouraging this work with his enthusiasm and expertise. D. E. Wheeler, D. M. Feener, L. Johnson and the Iowa Writing Seminar Group provided helpful comments on the manuscript. This work was supported by The Smithsonian Tropical Research Institute (DMW, EAH), The Harris Foundation (EAH), and The University of Iowa's Teaching and Research Fellowship Program (EAH). 


\section{SUMMARY}

Twelve species of vespid wasps were found nesting on two species of melastomataceous ant plants in a mixed lowland forest near Iquitos, Peru. Although eight different species of ants inhabited different individual plants of Tococa guianensis (Melastomataceae), wasps only nested on those plants inhabited by the ant Allomerus octoarticulatus. Nests were also found on Maieta poeppigii (Melastomaceae) inhabited by Pheidole spp. Several Mischocyttarus species exhibited nest architectures atypical of the group. Observations and manipulations indicate that by nesting on these ant plants inhabited by those particular ants the wasps avoid nest plundering by army ants.

\section{REFERENCES}

JEANNE, R. L.

1972. Social Biology of the Neotropical Wasp Mischocyttarus drewsenii. Bull. Mus. Comp. Zool., Harvard Univ. 144: 63-150.

1979. Construction and Utilization of Multiple Combs in Polistes canadensis in Relation to the Biology of a Predaceous Moth. Behav. Ecol. Sociobiol. 4, 293-310.

Kinsey, W. G. AND A. H. Gentry

1979. Habitat utilization in two species of Callicebus. in Primate Ecology: Problem Oriented Field Studies. R. W. Sussman ed. Wiley and Sons. New York.

LitTe, M.

1977. Behavioral ecology of the Social Wasp Mischocyttarus mexicanus. Behav. Ecol. Sociobiol. 2: 229-246.

RICHARDS, $O$. W.

1945. A Review of the Genus Mischocyttarus de Saussure. Trans. Roy. Entomol. Soc. London. 95: 295-462.

RICHARDS, O. W. AND M. J. RICHARDS.

1951. Observations on the Social Wasps of South America (Hymenoptera, Vespidae). Trans. Roy. Entomol. Soc. London. 102: 1-170.

Roтн, I.

1976. Estructura Interna de los Domacios Foliares en Tococa (Melastomeae). Acta Biol. Venez., 9(2): 221-258.

Vesey-Fitzgerald, D.

1938. Social Wasps (Hym. Vespidae) from Trinidad, with a note on the genus Trypoxylon Latreille. Trans. Roy. Entomol. Soc. London. 87: 181-191. WINDSOR, D. M.

1972. Nesting Association between two Neotropical Polybiine Wasps (Hymenoptera, Vespidae). Biotropica 4: 1-3. 
1973. Birds as Predators on the Brood of Polybia Wasps (Hymenoptera: Vespidae: Polistinae) in a Costa Rican Deciduous Forest. Briotropica 8(2): 111-116.

ZIKAN, J. F.

1949. O Genero Mischocyttarus Saussure (Hymenoptera, Vespidae), com a decriciao de 82 especies novas. VBoln. Parq. nac. Itatiaia 1: 1-251. 

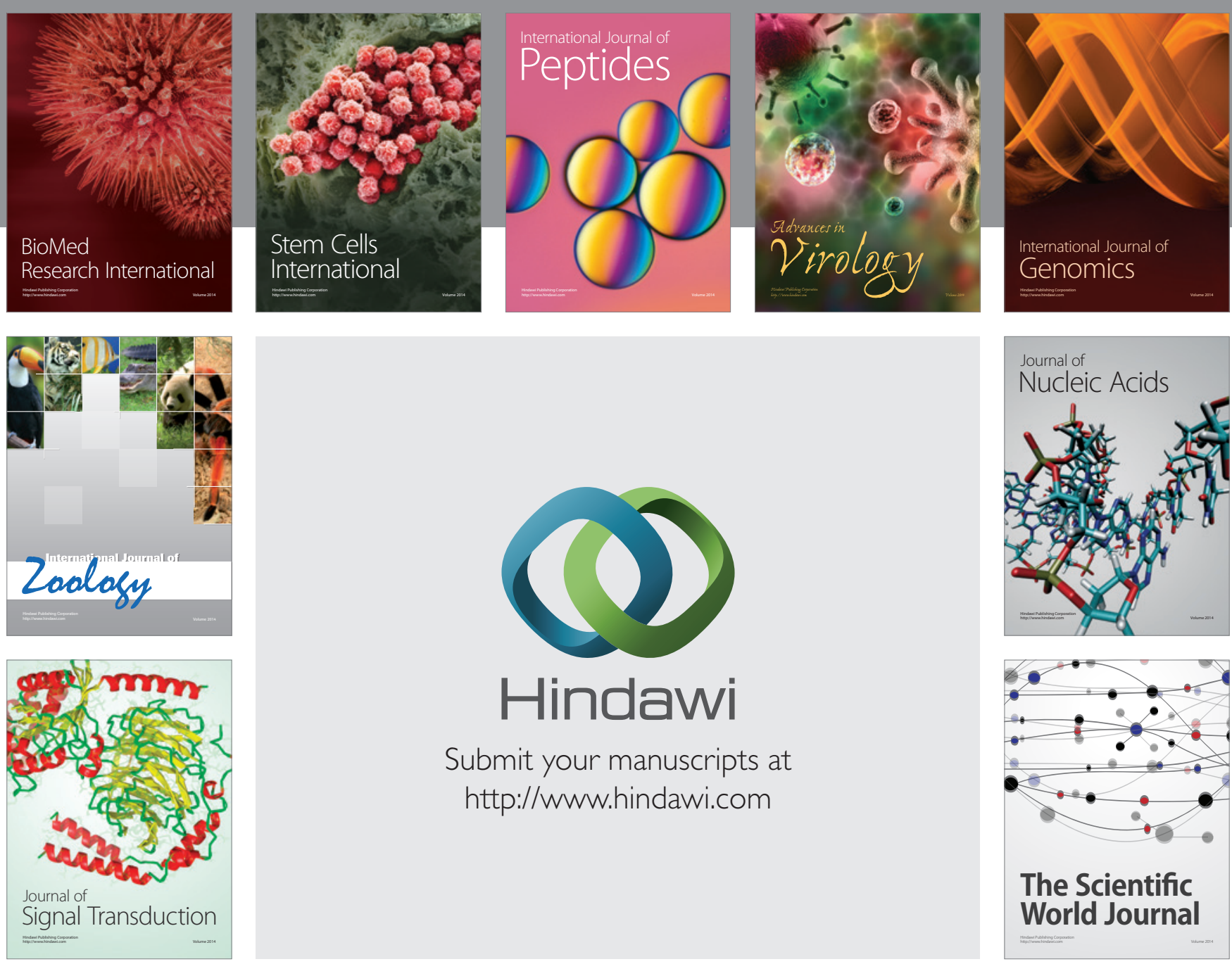

Submit your manuscripts at

http://www.hindawi.com
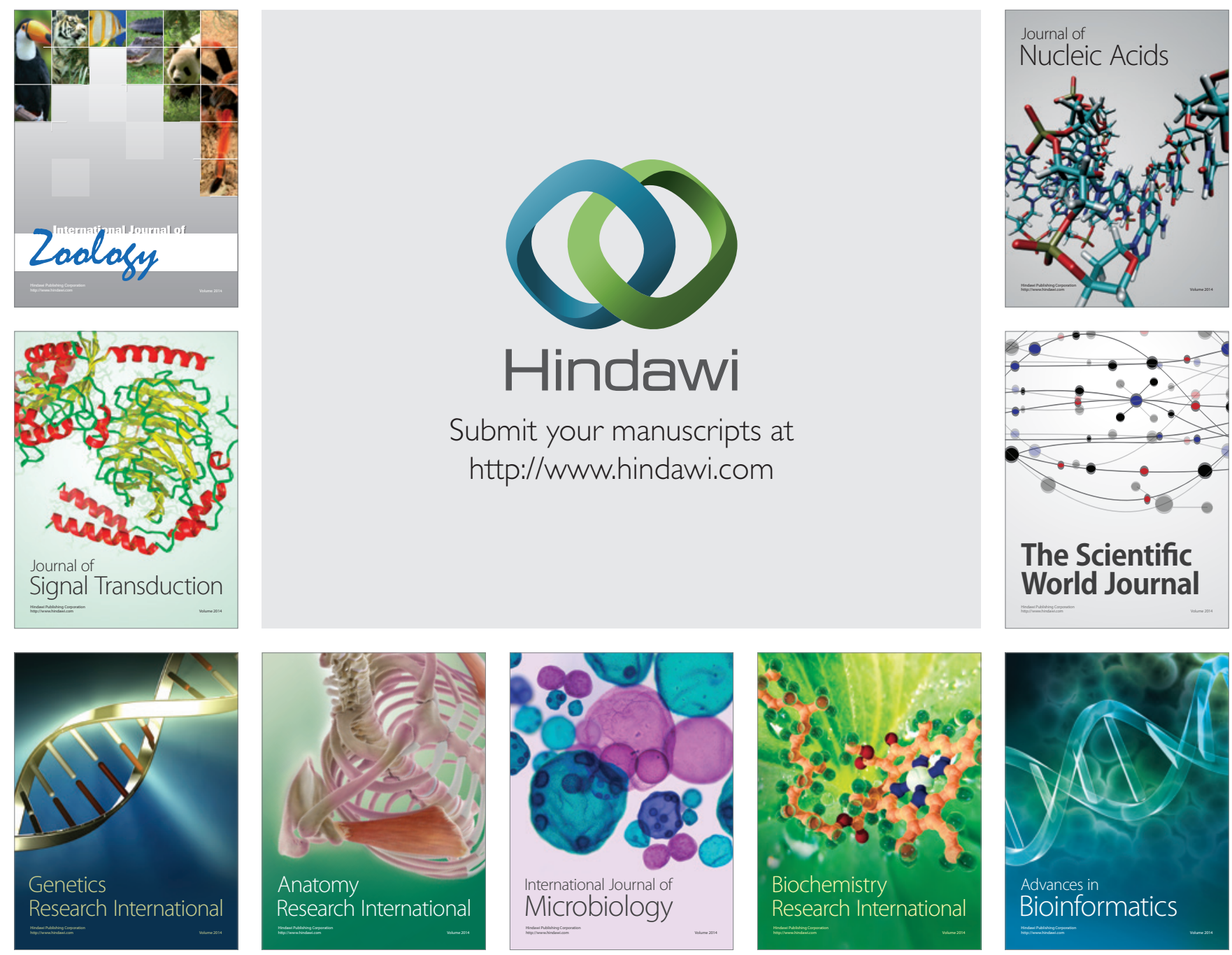

The Scientific World Journal
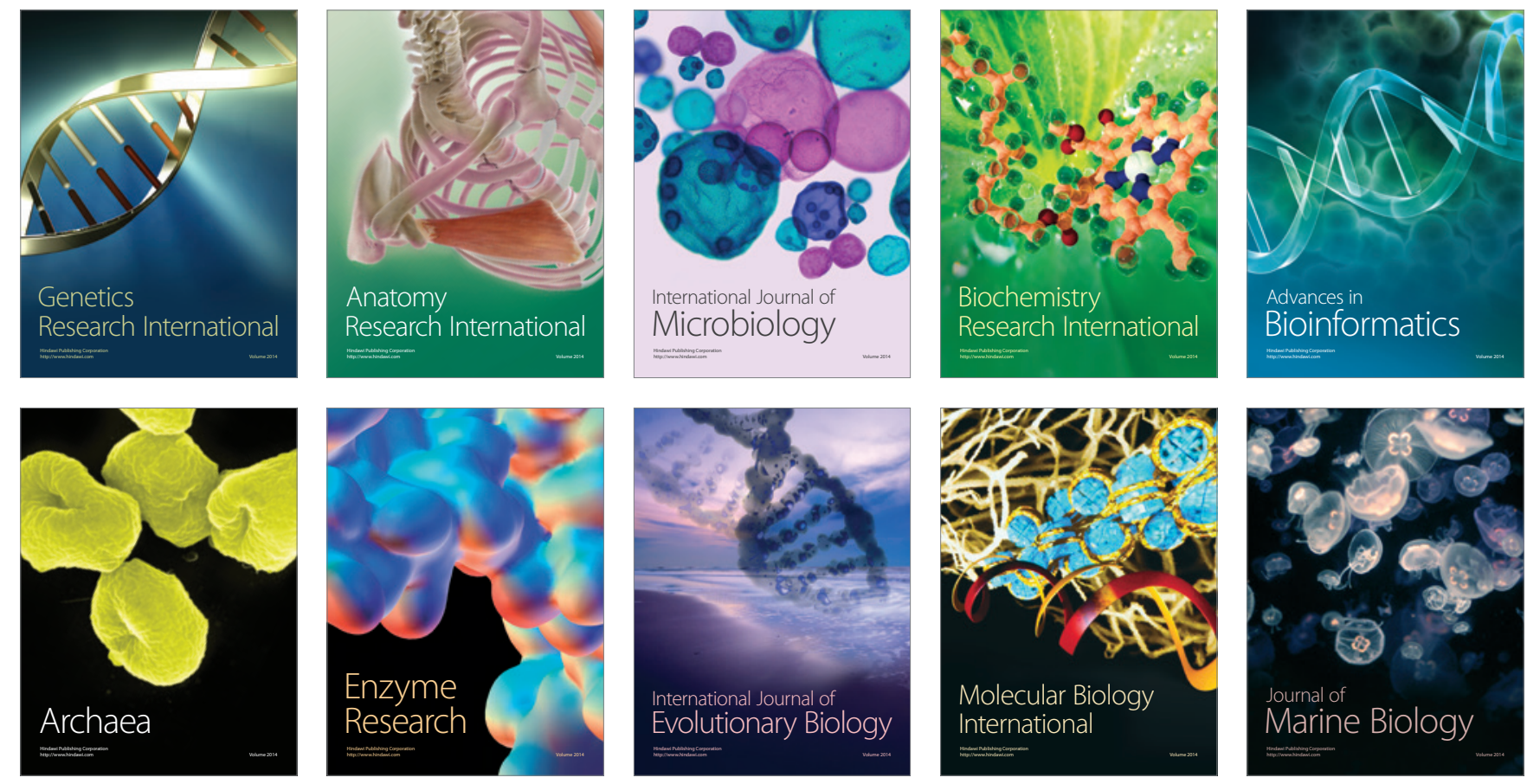